\title{
Effect of D-Fructose on Sugar Transport Systems in Trichoplusia ni Cells and Photolabeling of the Trichoplusia ni Cell-Expressed Human HepG2 Type Glucose Transport Protein
}

\section{Chong-Kee Lee*}

Department of Immunology, School of Medicine, Catholic University of Daegu, Daegu 705-718, Korea

Received November 6, 2013 /Revised December 20, 2013 /Accepted December 26, 2013

\begin{abstract}
Trichoplusia ni cells are used as a host permissive cell line in the baculovirus expression system, which is useful for large-scale production of human sugar transport proteins. However, the activity of endogenous sugar transport systems in insect cells is extremely high. Therefore, the transport activity resulting from the expression of exogenous transporters is difficult to detect. Furthermore, very little is known about the nature of endogenous insect transporters. To exploit the expression system further, the effect of D-fructose on 2-deoxy-D-glucose (2dGlc) transport by $T$. $n i$ cells was investigated, and T. ni cell-expressed human transporters were photolabeled with $\left[{ }^{3} \mathrm{H}\right]$ cytochalasin $\mathrm{B}$ to develop a convenient method for measuring the biological activity of insect cell-expressed transporters. The uptake of $1 \mathrm{mM} 2 \mathrm{dGlc}$ by uninfected- and recombinant AcMPV-GTL infected cells was examined in the presence and absence of $300 \mathrm{mM}$ of D-fructose, with and without $20 \mu \mathrm{M}$ of cytochalasin B. The sugar uptake in the uninfected cells was strongly inhibited by fructose but only poorly inhibited by cytochalasin B. Interestingly, the AcMPV-GTL-infected cells showed an essentially identical pattern of transport inhibition, and the rate of 2dGlc uptake was somewhat less than that seen in the non-infected cells. In addition, a sharply labeled peak was produced only in the AcMPV-GTL-infected membranes labeled with $\left[{ }^{3} \mathrm{H}\right]$ cytochalasin $B$ in the presence of L-glucose. No peak of labeling was seen in the membranes prepared from the uninfected cells. Furthermore, photolabeling of the expressed protein was completely inhibited by the presence of D-glucose, demonstrating the stereoselectivity of labeling.
\end{abstract}

Key words : Baculovirus expression system, Trichoplusia mi cells, hexose transport, photolabelling

\section{서 론}

포도당은 대부분의 포유동물 세포의 주요 에너지원이다. 포 도당의 친수성(hydrophylic nature)은 이들 분자가 단순 확산 에 의해 세포막을 통과 할 수 없게 만들며, 이들 분자의 에너지 비 의존성 세포 내 영입은 특수한 세포막 수송체(membrane transporters)들을 통해서 이루어지게 한다. 분자생물학의 발 달은 유전자 염기서열 비교를 가능케 하였으며, 현재 포도당 수송 단백질들은 그들의 구조와 기능의 특성에 따라 크게 두 가지 큰 수송 단백질 집단으로 존재하고 있음이 밝혀져 있다: $\mathrm{Na}^{+}$/glucose cotransporter family (SGLT/ SLC5A)와 facilitative glucose transporter family (GLUT/ SLC2A) $[7,15,25]$.

GLUT 단백질 집단은 현재까지 14 개의 다른 멤버들로 구성 되어 있으며 밝혀진 염기서열 상동성(sequence homology)에

\footnotetext{
*Corresponding author

Tel : +82-53-650-4477, Fax : +82-53-650-4477

E-mail : leeck@cu.ac.kr

This is an Open-Access article distributed under the terms of the Creative Commons Attribution Non-Commercial License (http://creativecommons.org/licenses/by-nc/3.0) which permits unrestricted non-commercial use, distribution, and reproduction in any medium, provided the original work is properly cited.
}

따라 다시 class I, class II, class III의 세 그룹으로 나누어진다 [21]. 이러한 사실들은 당 수송체들이 공동의 조상으로부터 진 화되었음을 암시하고 있어, 이들 집단 중 어느 한 수송 단백질 의 당 수송 기전이나, 삼차원적인 구조를 정확히 밝혀 낼 수 있다면 이는 당과 연관된 질환 기전의 이해, 예방 또는 치료약 물 개발에도 크게 기여 할 수 있게 될 것이다. 그러나 아쉽게도 지난 몇 십 년간의 노력에도 불구하고 적혈구(erythrocyte) 또 는 사람 간암세포(hepatocellular carcinoma) HepG형 수송체 를 포함하는 GLUT class I 그룹뿐 아니라, 나머지 그룹의 어떤 멤버에 대한 3차원적 구조도 아직 밝혀내지 못하고 있는 실정 이다[21]. 장애요인 중 하나로는 사람 세포막 내에 존재하는 $\mathrm{HepG} 2$ 형 포도당 수송 단백질들의 원래 양 만으로는 결정체를 이용한 생물리학적 연구나, 구조와 기능의 상관관계 연구 등 에 필요한 충분한 양의 단백질 확보에 어려움이 있다. 뿐만 아니라 nucleoside 수송체와 같은 물질들로 오염 되기 또한 쉬워서, 순수한 HepG2형 수송 단백질만을 분리, 정제하기도 쉽지 않다[6]. 이러한 연유로 당 수송체들을 E. coli [17, 22], Xenopus oocytes [5, 9], mammalian cells [1], transgenic mice [14], yeast $[8,24]$ 등을 이용해 발현하고자 하는 다양한 유전공 학적 발현 노력들이 있어 왔다. 그러나 막 단백질(membrane proteins)들이 갖는 특성으로 인해 단지 소량의 기능성 있는 
단백질 생산만이 가능하였다. 반면에 baculovirus와 곤충세포 를 이용한 발현 시스템은 다량의 사람 당 수송체의 이성질적 생산 가능성과 염기 치환된 mutant 사람 당 수송체의 곤충 세포발현 가능성을 보여주었다[3, 11, 19, 23, 26]. 그러나 바이 러스의 복제를 허용하는 숙주인 곤충세포에 존재하는 내재된 당 수송체의 높은 활동으로 인해 발현된 당 수송체 활성의 직접적 증거 제시에는 실패하였다. 그러므로 곤충세포를 이용 한 이성질적 발현 시스템의 보다 효율적 활용을 위해서는 숙 주세포에 내재하는 당 수송체의 활동을 억제하거나, 이들의 영향과 활동에 방해 받지 않고도 발현된 당 수송체의 생물학 적 기능을 보다 용이하게 측정 할 수 있는 방법 등의 확보가 필요하다. 아울러 곤충세포 내재 당 수송체의 특성에 대해서 도 더욱 많은 정보가 요구되고 있다. Baculovirus의 숙주세포 로서 최근 Trichoplusia ni 세포가 여러 유형의 단백질 발현 숙 주세포로 그 영역을 넓혀가고 있다[10,16]. 그러나 이 숙주세 포에 내재하는 당 수송체계의 특성에 대해서도 밝혀진 바가 거의 없는 실정이다. 따라서 본 연구에서는 $T . n i$ 곤충 세포에 내재된 당 수송체의 기질로 D-fructose가 2-deoxy-D-glucose 수송에 미치는 영향을 살펴보았고, 발현된 전환 수송체에 자 외선과 강력한 억제제를 이용한 ligand labeling으로 발현 수 송체의 생물학적 활성을 검증하였다.

\section{재료 및 방법}

\section{곤충세포 배양 및 plasma membranes 준비}

T. $n i$ 곤충 세포로는 High Five cell line (BTI-TN-5B1-4, Invitrogen)을 이용하여, Summers와 Smith의 방법[20]을 변형 하여 배양하였다. 세포의 배양액으로는 TNM-FH (Trichoplusia $n i$ Medium-Formulation Hink, Invitrogen)를 사용하여 $27^{\circ} \mathrm{C}$ 에서 $\mathrm{CO}_{2}$ 없이 배양하였다. TNM-FH에 $10 \% \mathrm{FCS}, 1 \%$ of antibiotics (Gentamycin at $10 \mu \mathrm{g} / \mathrm{m}$ ) 첨가한 완전 배지를 단계적 으로 사용하였다. 세포 계대 배양은 monolayer 형성 시 이루 어졌으며, 세포의 활성여부는 $0.1 \mathrm{ml}$ trypan blue $(0.4 \%$ stock, $\mathrm{pH}$ 3.0)를 $1 \mathrm{ml}$ 세포에 첨가하여 현미경 아래서 관찰하여 이용 하였으며, 배양 된 세포는 4-5일 후 수거하여 세 번 세척액(10 $\mathrm{mM}$-sodium phosphate/150 mM-NaCl, pH 7.2)으로 씻었다. 그 후 단백분해효소 억제제 $(2 \mathrm{mM}$-iodoacetamide, $0.2 \mathrm{mM}$ phenylmethanesulphonyl fluoride, pepstatin A, $10 \mathrm{~g} / \mathrm{ml}$ ) 들 을 함유하는 부양액 $\left(10 \mathrm{mM}\right.$-Tris $\left./ 5 \mathrm{mM}-\mathrm{MgCl}_{2} \mathrm{pH} 7.4\right)$ 을 $0^{\circ} \mathrm{C}$ 에서, 1 분간 sonication하여 $117,000 \times g_{\mathrm{av}}$ 로 1 시간 동안 원심 분리하여 soluble fraction 으로부터 membrane fraction을 분 리하였다.

\footnotetext{
Recombinant baculovirus 생산 및 mutant 사람 당 수 송체의 발현

사람 transporter 유전자를 포함하는 recombinant baculovirus 생산은 Summers와 Smith의 방법[20]을 기반으로 한
}

transfection mannual에 따라 leucine (282) 치환된 HepG2형 당 수송체의 전체 coding region을 포함하는 recombinant baculovirus vector DNA를 wild-type baculovirus viral DNA (BaculoGold, PharMingen)와 함께 숙주세포에 co-transfection시켜 in vivo recombination을 유도함으로써 recombinant virus (AcMPV-GTL)를 생산하였다[11]. 그 후 $T . n i$ 세포 를 96-well plate에 $1.5 \times 10^{4}$ cells/well로 seeding 한 후 plaque assay를 통해 얻은 바이러스를 $10^{1}-10^{8}$ 으로 serial dilution 시 킨 다음, well 당 $50 \mathrm{ul}$ 의 바이러스로 감염시켜 $28^{\circ} \mathrm{C}$ 에서 5 일간 배양하였다. HepG2형 전환 당 수송 단백질을 발현하는 recombinant baculovirus를 최종적으로 확인생산하기 위해서, sodium hydroxide로 용해시킨 세포액을 dot-blot 장치를 사용 하여 nitrocellulose에 전위 시킨 후 HepG2형 C-terminus 대한 일차항체와 phosphatase-conjugate된 이차 항체를 이용한 limiting dilution assay를 활용하였다[12].

\section{Sugar transport assay}

간략히 설명하면 $1 \mathrm{ml}$ 세포 현탁액 $\left(1 \times 10^{6}\right.$ cells $\left./ \mathrm{ml} \mathrm{PBS}\right)$ 을 $6,000 \times g$ 에서 15 초 동안 원심 분리하여 $150 \mu \mathrm{l}$ 의 $\mathrm{PBS}$ 용액에 다시 현탁 시킨 후 $27^{\circ} \mathrm{C}$ 에서 2 분간 배양하였다. Transport에 사용된 tritiated sugars들은 2-(1,2- $\left.{ }^{3} \mathrm{H}\right)$-deoxy-D-glucose (2 $\mathrm{dGlc}, 30.2 \mathrm{Ci} / \mathrm{mmol})$ 와 L-[1- $\left.{ }^{3} \mathrm{H}(\mathrm{N})\right]$-glucose $(10.7 \mathrm{Ci} / \mathrm{mmol})$ 였다. T. ni 곤충세포의 $2 \mathrm{dGlc}$ uptake 측정을 위해서는 측정 전 두 번 phosphate-buffered saline (PBS, $10 \mathrm{mM}$ sodium phosphate, $150 \mathrm{mM} \mathrm{NaCl}, \mathrm{pH}$ 7.4)으로 곤충세포를 씻어 배양

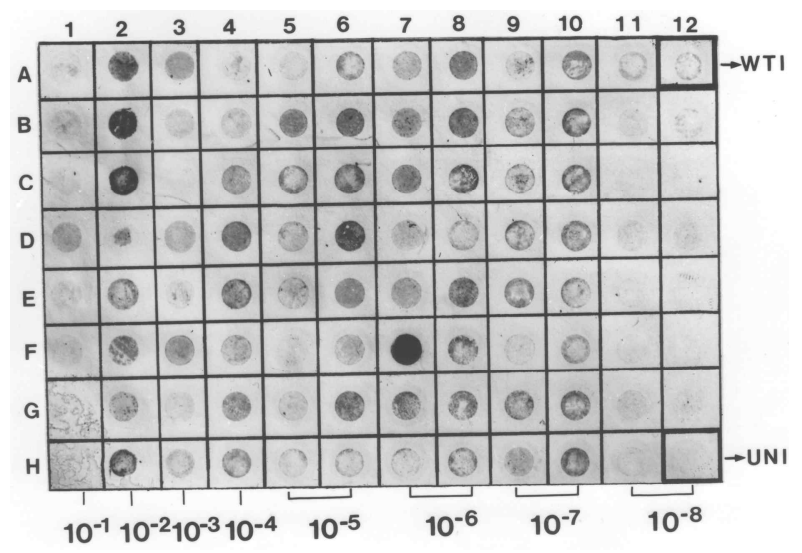

Fig. 1. Detection of recombinant viruses expressing human transporters by limiting dilution and immunostaining. T. ni cells were infected with $50 \mu \mathrm{l}$ of 10 -fold dilutions of virus prepared from the eight individual plaques, ranging from $10^{-1}$ to $10^{-8}$. The assay was performed as described in Summers and Smith [20]. Viruses (AcMPVGTL) expressing HepG2 type transporter were detected by Western blotting using antibodies against the $C$-terminus of HepG2 type transporter and alkaline phosphatase-conjugated goat anti-rabbit IgG. WTI: wild-type infected cells. UNI: uninfected cells as a negative control. 
액 속에 잔류된 포도당을 제거하였고 필요할 때까지 얼음에 보관하였다가 사용하였다. Transport는 최종 당 농도 $1 \mathrm{mM}$ 주기 위해 $1 \mu \mathrm{Ci}$ tritiated sugar를 함유하는 $2.5 \mathrm{mM} 2 \mathrm{dGlc}$ $100 \mu 1$ 를 첨가하면서 시작되었다. $27^{\circ} \mathrm{C}$ 에서 1 분간 배양 후 강력한 glucose transport 저해제인 $10 \mu \mathrm{M}$ cytochalasin B와 $0.1 \mathrm{mM}$ phloretin을 함유한 얼음에 차게 한 $1 \mathrm{ml} \mathrm{PBS}$ 를 첨가 하고 2,000× $\mathrm{g}$ 에서 20 초간 원심분리 하여 transport assay를 끝마쳤다. 세포들은 위와 같은 방법으로 두 번 더 세척하여 $10 \%$ SDS $200 \mu \mathrm{ll}$ 에 vortexing하여 용해하였다. 마지막으로 $150 \mu \mathrm{l}$ 의 용해된 세포를 Microman pipette을 이용하여 $4 \mathrm{ml}$ 의 scintillant 용액이 담긴 용기에 넣고 liquid scintillation counter (LS 5,000 CE)를 이용하여 방사능을 측정하였다. 모든 결과들은 세 번 측정치의(평균보다 $10 \%$ 이하의 차이) 평균값 으로 표시하였다.

Photoaffinity labeling of $T$. ni cell-expressed human glucose transport proteins

Mutant HepG2형 포도당 수송체의 photoaffinity labeling 은 tritiated cytochalasin $\mathrm{B}$ 를 사용하여 알려진 방법으로 실행 하였다 [2, 4]. T. ni 세포 membrane 샘플 $(1 \mathrm{mg}$ protein $/ \mathrm{ml}$ in $50 \mathrm{mM}$ sodium phosphate, $\mathrm{pH}$ 7.4, $100 \mathrm{mM} \mathrm{NaCl}, 1 \mathrm{mM}$ EDTA \& $500 \mathrm{mM}$ D-or L-glucose)을 binding equilibrium 달 성을 위해 얼음에서 30 분 동안 $0.51 \mu \mathrm{M}\left[{ }^{3} \mathrm{H}\right]$-cytochalasin $\mathrm{B}$, cytochalasin $\mathrm{E}(10 \mu \mathrm{M})$ 와 함께 배양하였고, $\mathrm{N}_{2}$ 로 채워진 1 $\mathrm{ml}$ cuvette에 옮겨 $100 \mathrm{~W} \mathrm{UV} \mathrm{lamp를} \mathrm{사용하여} 10 \mathrm{~cm}$ 거리 에서 10 분간 방사선을 조사하였다. UV조사된 샘플들은 ultracentrifuge tubes (Beckman)로 옮겨 세척액 $(50 \mathrm{mM}$ sodium phosphate, $100 \mathrm{mM} \mathrm{NaCl}, 1 \mathrm{mM}$ EDTA pH 7.4, $20 \mu \mathrm{M}$ unlabelled cytochalasin B)으로 $4^{\circ} \mathrm{C}$ 에서 10 분간 $126,000 \times g$ 로 2 번 원심분리 세척하여, 공유결합 되지 않은 - $\left.{ }^{3} \mathrm{H}\right]-$ cytochalasin B를 제거하였다. 세척 된 샘플은 $(100 \mu \mathrm{g})$ 두께 $3 \mathrm{~mm}, \mathrm{SDS} / 12 \%$ polyacrylamide gel을 사용하여 전기 영동, 고정, Coomassie Blue 염색 및 탈색 처리하였다. 적절한 gel 트랙을 $1 \mathrm{~cm}$ 넓이로 자른 후 gel slicer를 이용 $2 \mathrm{~mm}$ slices 로 잘라, scintillation counter 용기에 넣어 $50^{\circ} \mathrm{C}$ 에서 3시간 $1 \mathrm{ml} \mathrm{50 \%} \mathrm{(v/v)} \mathrm{Solvable} \mathrm{(Du} \mathrm{Pont} \mathrm{GMBH,} \mathrm{Germany)} \mathrm{용액과}$ 함께 배양 한 후 $4 \mathrm{ml}$ scintillation 용액을 각 용기에 더한 후 scintillation counter (Beckman)를 이용하여 방사능을 측정하 였다. 모든 결과들은 세 번 측정치의(평균보다 $10 \%$ 이하의 차 이) 평균값으로 표시하였다.

\section{결과 및 고찰}

T. ni 세포는 양배추 애벌레(cabbage looper)의 난소세포에 서 유래되어서, 발전되고 널리 활용되고 있는 baculovirus의 단백질 합성과 증식을 허용하는 숙주세포이다[16]. 그런데 이 세포의 배양을 위해 사용되는 배양액에는 주 탄소 원으로
$0.1 \%$ D-glucose가 함유되어 있으며, 이들 세포는 이러한 환경 에서 잘 자랄 수 있다. 이러한 사실은 T. ni 곤충세포에도 당의 세포 내 영입을 주도하는 sugar transport system이 내재하고 있다는 사실을 암시한다. GLUT class I family에 속하는 사람 $\mathrm{HepG} 2$ 형 포도당 수송체의 단순 당들에 대한 기질 친화성 (substrate affinity)에 대한 특성은 비교적 잘 알려져 있다[13]: 2-deoxy-D-glucose $>$ D-glucose $>$ D-mannose $>$-- >>L-glucose. 이 수송체는 D-stereoisomer에 강한 특이성을 가지는 입체 선 택성(stereoselectivity)을 보이나, D-fructose에 대한 친화성은 $\mathrm{Km} 1.5 \mathrm{M}$ 로 매우 낮은 것으로 알려져 있다[13]. 반면에 T. $\mathrm{ni}$ 에 내재하는 당 수송체의 기질에 대한 특이성은 알려진 바가 거의 없는 실정이다. 그러나 Fig. 2와 Fig. 3의 transport assay 결과에서 나타난, $T . n i$ 세포에 내재된 당 수송체는 사람 $\mathrm{HepG} 2$ 형 당 수송체 와는 다른 기질 특이성을 보였다. Glucose 의 이성체이며 ketone 기를 가지는 대표적인 ketohexose인 D-fructose에 대해 사람 HepG2형 당 수송체 와는 달리 상대적 으로 강한 친화성을 보여 주었다. 감염시키지 않은, $T . n i$ 숙주 세포에 내재된 당 수송체의 $2 \mathrm{dGlC}$ transport 활동이 $300 \mathrm{mM}$ D-fructose에 의해 강력히 억제되었다. 반면에 사람 HepG2형 당 수송체에 $K_{d}$ 약 $0.12 \mu \mathrm{M}$ 로 결합하는 강력한 억제제인 cytochalasin B에 대해서는[18] 미미한 억제 효과만을 보여주었 다. 또한AcMPV-GTL 바이러스 감염된 $T . n i$ 세포에서도 이러 한 유형은 근본적으로 동일하게 나타났다. 비록 2dGlc uptake 율은 감염되지 않은 세포와 비교해 다소 낮았지만 D-fructose

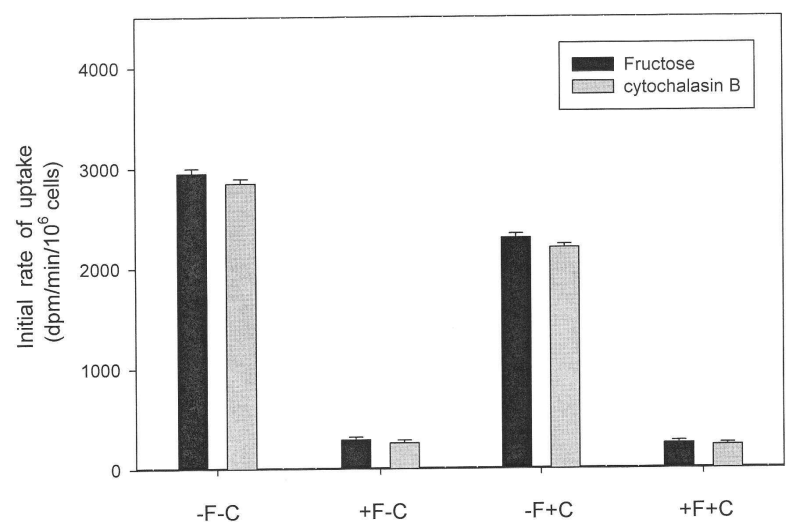

Fig. 2. Uptake of $1 \mathrm{mM}$ 2-deoxy-D-glucose by uninfected- and recombinant virus infected T. ni cells. Cells were infected with recombinant AcMPV-GTL or no virus $(\mathrm{MOI}=5)$ as described in Materials and Methods. After 2 days infection cells were collected and resuspended in PBS plus $(+)$ and $(-) 300 \mathrm{mM}$ D-fructose, and plus (+) and (-) 20 $\mu \mathrm{M}$ cytochalasin B. Transport was carried out as described in Materials and Methods. Bars represent mean \pm SEM for three measurements assayed in triplicate. Black bar: uninfected cells. Grey bar: recombinant AcMPV-GTL-infected cells. F: D-fructose. C: cytochala$\sin \mathrm{B}$. 


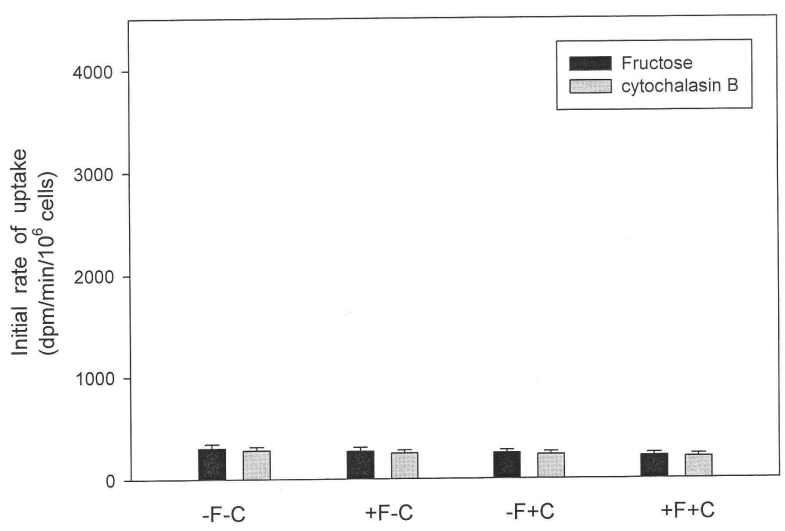

Fig. 3. Uptake of $1 \mathrm{mM}$ L-glucose by uninfected- and recombinant virus infected T. ni cells. Cells were infected with recombinant AcMPV-GTL or no virus $(\mathrm{MOI}=5)$ as described in Materials and Methods. After 2 days infection cells were collected and resuspended in PBS plus $(+)$ and (-) $300 \mathrm{mM}$ D-fructose, and plus (+) and (-) $20 \mu \mathrm{M}$ cytochalasin B. Transport was carried out as described in Materials and Methods. Bars represent mean \pm SEM for three measurements assayed in triplicate. Black bar: uninfected cells. Grey bar: recombinant AcMPV-GTL-infected cells. F: D-fructose. C: cytochalasin B.

에 민감하며 cytochalasin B에는 민감하지 않은 리간드 유형을 보여주었다. 다시 말해 발현된 사람 당 수송체로 인해 감염된 곤충세포의 2dGlc uptake 에 영향을 줄 수 있는 새로운 요소, 즉 cytochalasin B 에는 민감하나 fructose에는 민감하지 않은 요소의 등장은 관찰되지 않았다. 따라서 사람 HepG2형 당 수 송체의 강력한 억제제인 cytochalasin B를 이용하여, 면역 항 체에 의해 확인한 T. ni 숙주 세포에 발현된 사람 당 수송체 (Fig. 1) 가 D-glucose민감한, cytochalasin B 결합부위를 가지 는 단백질임을 보이기 위해 ligand photoaffinty labeling을 실

A

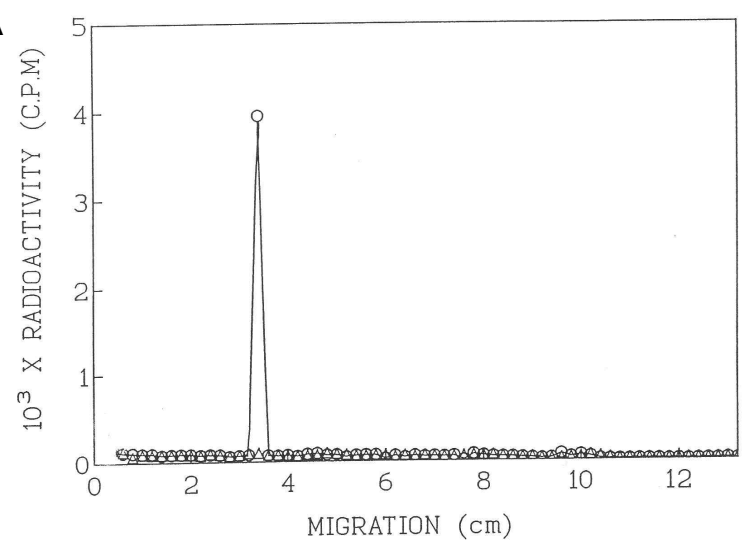

행하였다. 사람 적혈구형 당 수송체에 대한 이 억제제의 결합 은 가역적인데, tritiated cytochalasin B이 존재하는 상황에서 자외선(ultraviolet)을 조사하면 억제제는 당 수송체에 비가역 적 공유결합을 하게 되는 원리이다[18]. Fig. $4 \mathrm{~A}$ 에서 볼 수 있 듯이 L-glucose 존재 하에서는 $\left[{ }^{3} \mathrm{H}\right]$ cytochalasin B로 표지 된 membrane 시료에서 약 $\mathrm{M}_{\mathrm{r}} 45,000$ 의 (SDS/PAGE상), 하나의 날카로운 peak가 관찰되었다. 게다가 이 peak는 D-glucose 존 재 하에서는 완전히 억제됨으로써(Fig. $4 \mathrm{~B}$ ), 사람 당 수송체가 가지는 D-stereoisomer에 대한 입체선택성(stereoselectivity) 을 나타내었다. 물론 발현된 당 수송체의 당 수송 능력의 직접 적 입증을 위해서는 다소 지루하면서도 노력이 필요한, 발현 단백질의 순수 정제 후 reconstitution 을 통한 당 수송 능력 측정법이 요구된다. 그러나 본 연구를 통해 나타난 바와 같이 T. ni 세포에 발현된 사람 당 수송체의 생물학적 활성 측정 시에 fructose를 이용한 억제와, 발현된 수송체의 억제제를 이 용한 photo-labeling은 곤충세포에 발현된 당 수송체의 생물학 적 활성을 용이하게 입증 할 수 있는 또 다른 수단이 될 수 있음을 보여주었다.

\section{감사의 글}

본 연구는 대구가톨릭대학교 2012년도 교내연구비 지원 사 업에 의해 (부분)지원 되었으므로 이에 감사드립니다.

\section{References}

1. Asano, T., Shibasaki, Y., Ohno, S., Taira, H., Lin, J. L., Kasuga, M., Kanazawa, Y., Akanuma, Y., Takaku, F. and Oka, Y. 1989. Rabbit brain glucose transporter responds to insulin when expressed in insulin-sensitive Chinese hamster ovary cells. J Biol Chem 264, 3416-3420.

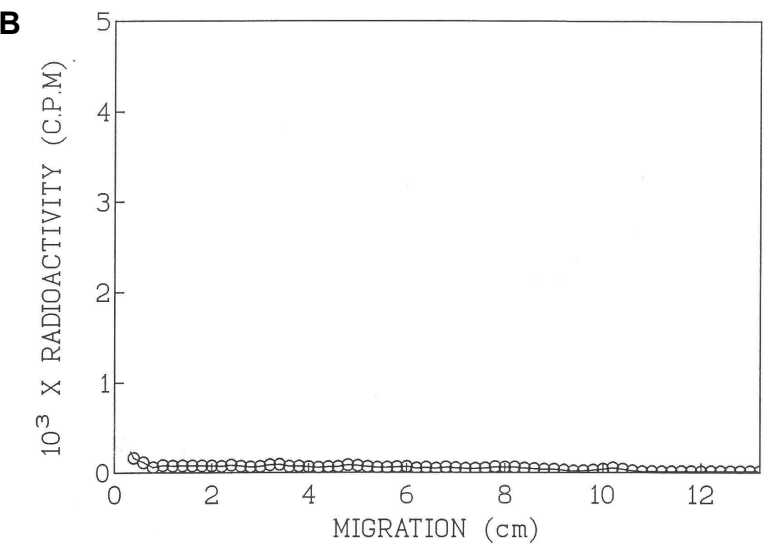

Fig. 4. (A) Electrophoretic profile of photoaffinity-labelled HepG2 transporter expressed in T. ni cells. Membranes were labelled with $\left[^{3} \mathrm{H}\right]$ cytochalasin $\mathrm{B}$ in the presence of $500 \mathrm{mM}$-L-glucose $(\mathrm{O})$ or $500 \mathrm{mM}$-D-glucose $(\triangle)$. Samples were electrophoresed on a SDS/12\% polyacrylamide gel. The radioactivity of $2 \mathrm{~mm}$ gel slices were determined by liquid scintillation counting. (B) Electrophoretic profile of photoaffinity labelling of uninfected T. ni cells. Uninfected T. ni cell membranes were photoaffinity-labelled with $\left[{ }^{3} \mathrm{H}\right]$ cytochalasin $\mathrm{B}$ in the presence of $500 \mathrm{mM}$-L-glucose, as described in the legend to Fig. $4 \mathrm{~A}$. 
2. Carter-Su, C., Pessin, J. E., Mora, R., Gitomer, W. and Czech, M. P. 1982. Photoaffinity labeling of the human erythrocyte D-glucose transporter. J Biol Chem 257, 5419-5425.

3. Cope, D. L., Holman, G. D., Baldwin, S. A. and Wolstenholme, A. J. 1994. Domain assembly of the GLUT1 glucose transporter. Biochem J 300, 291-294.

4. Deziel, M., Pegg, W., Mack, E., Rothstein, A. and Klip, A. 1984. Labeling of the human erythrocyte glucose transporter with ${ }^{3}$ H-labelled cytochalasin B occurs via protein photoactivation. Biochim Biophys Acta 772, 403-406.

5. Gould, G. W. and Lienhard, G. E. 1989. Expression of a functional glucose transporter in Xenopus oocytes. Biochemistry 28, 9447-9452.

6. Jarvis, S. M. and Young, J. D. 1981. Extraction and partial purification of the nucleoside-transport system from human erythrocytes based on the assay of nitrobenzylthioinosinebinding activity. Biochem J 194, 331-339.

7. Joost, H. G. and Thorens, B. 2001. The extended GLUT-family of sugar/polyol transport facilitators: nomenclature, sequence characteristics, and potential function of its novel members. Mol Membr Biol 18, 247-256.

8. Kasahara, T. and Kasahara, M. 1996. Expression of the rat GLUT1 glucose transporter in the yeast Saccharomyces cerevisiae. Biochem J 315, 177-182.

9. Keller, K., Strube, M. and Mueckler, M. 1989. Functional expression of the human HepG2 and rat adipocyie glucose transporters in xenopus oocytes. J Biol Chem 32, 18884-18889.

10. Krammer, F., Schinko, T., Palmberger, D., Tauer, C., Messner, P. and Grabherr, R. 2010. Trichoplusia ni cells (High Five) are highly efficient for the production of influenza A virus-like particles: a comparison of two insect cell lines as production platforms for influenza vaccines. Mol Biotechnol $45,226-234$.

11. Lee, C. K. 2008. Functional assessments of Spodpotera cell-expressed human erythrocyte-type glucose transport protein with a site-directed mutagenesis. J Exp Biomed Sci 14, 119-122.

12. Lee, C. K. 2010. Expression of polyhistidine-containing fusion human HepG2 type glucose transport protein in Spodoptera cells and its purification using a metal affinity chromatography. J Exp Biomed Sci 16, 201-206.

13. LeFevre, P. G. 1961. Sugar transport in the red blood cell: structure-activity relationships in substrates and antagonists. Pharmacol Rev 13, 39-70.
14. Liu, M. L., Olson, A. L., Moye-Rowley, W. S., Buse, J. B., Bell, G. I. and Pessin, J. E. 1992. Expression and regulation of the human GLUT4/muscle-fat facilitative glucose transporter gene in transgenic mice. J Biol Chem 267, 11673-11676.

15. Manolescu, A. R., Witkowsk, K., Kinnaird, A., Cessford, T. and Cheeseman, C. 2007. Facilitated hexose transporters: new perspectives on form and function. Physiology 22, 234-240.

16. O'Reilly, D. R., Miller, L. K. and Luckow, V. A. 1992. Baculovirus Expression Vectors: A Laboratory Manual, W. H. Freeman and Company, New York, USA.

17. Sarkar, H. K., Thorens, B., Lodish, H. F. and Kaback, H. R. 1988. Expression of the human erythrocyte glucose transporter in Escherichia coli. Proc Natl Acad Sci 85, 5463-5467.

18. Shanahan, M. F. 1982. Cytochalasin B: A natural photoaffinity ligand for labeling the human erythrocyte glucose transporter. J Biol Chem 257, 7290-7293.

19. Smith, C. D., Hirayama, B. A. and Wright, E. M. 1992. Baculovirus-mediated expression of the $\mathrm{Na}+$ glucose cotransporter in Sf9 cells. Biochim Biophys Acta 17, 151-159.

20. Summers, M. D. and Smith, G. E. 1987. A manual of methods for baculovirus vectors and insect cell culture procedures. Tex Agric Exp Stn Bull No. 1555.

21. Thorens, B. and Mueckler, M. 2010. Glucose transporters in the 21st century. Am J Physiol Endo 298, E141-E145.

22. Thorens, B., Sarkar, H. K., Kaback, H. R. and Lodish, H. F. 1988. Cloning and functional expression in bacteria of a novel glucose transporter present in liver, intestine, kidney, and B-pancreatic islet cells. Cell 55, 281-290.

23. Weinglass, A. B. and Baldwin, S. A. 1996. Characterisation and purification of recombinant GLUT1 expressed in insect cells. Biochem Soc Trans 24, 478S.

24. Wieczorke, R., Dlugai, S., Krampe, S. and Boles, E. 2003. Characterisation of mammalian GLUT glucose transporters in a heterologous yeast expression system. Cell Physiol Biochem 13, 123-134.

25. Wright, E. M., Loo, D. D. and Hirayama, B. A. 2011. Biology of human sodium glucose transporters. Physiol Rev 91, 733-794.

26. Yi, C. K., Charalambous, B. M., Emery, V. C. and Baldwin, S. A. 1992. Characterization of functional human erythrocyte-type glucose transporter expressed in insect cells using a recombinant baculovirus. Biochem J 283, 643-646. 


\section{초록 : Trichoplusia ni 세포에 내재하는 당 수송체에 D-fructose가 미치는 효과와 Trichoplusia ni 세포에 발현된 사람 HepG2형 포도당 수송 단백질의 photolabelling \\ 이종기* \\ (대구가톨릭대학교 의과대학 면역학교실)}

Trichoplusia ni $(T, n i)$ 세포는 사람 당 수송체를 이성질적으로 많은 양 생산하려 할 때 유용하게 사용되는, baculovirus 발현 시스템의 숙주세포로서 이용된다. 그러나 $T . n i$ 세포에 존재하는 내재된 당 수송체의 높은 활동은, 발현된 외재적 당 수송체의 수송활성과 같은 직접적 증거 제시에 장애가 된다. 뿐만 아니라 곤충세포에 내재하는 당 수송체계의 특성에 대해서는 밝혀진 바가 거의 없다. 그래서 본 연구에서는 baculovirus 발현 시스템을 보다 잘 활용하기 위해 $T . n i$ 세포의 $2 \mathrm{dGlc}$ 기질 수송에 D-fructose가 미치는 영향을 살펴 보았으며, $T . n i$ 세포에 발현된 사람 당 수송체의 생물학적 활성을 보다 용이하게 검증하기 위해 발현된 수송체를 $\left.{ }^{3} \mathrm{H}\right]$ cytochalasin $\mathrm{B}$ 를 이용하 여 photolabelling 하였다. 우선 감염되지 않은 세포와 recombinant AcMPV-GTL 감염시킨 T. ni 세포의 $2 \mathrm{dGlc}$ uptake를 $300 \mathrm{mM}$ D-fructose가 있을 때와 없을 때, 그리고 $20 \mu \mathrm{M}$ cytochalasin B가 있을 때와 없을 때의 상황에 서 살펴보았다. 감염되지 않은 세포에서의 육탄당 uptake는 D-fructose에 의해 강력하게 억제 되었으나 cytochala$\sin \mathrm{B}$ 에 의해서는 단지 미미한 억제 효과만을 보여주었다. 흥미롭게도 AcMPV-GTL 바이러스 감염된 T. ni 세포에 서는 비록 $2 \mathrm{dGlc}$ uptake율은 감염되지 않은 세포와 비교해 다소 낮았지만 육탄당 수송 억제 반응은 근본적으로 동일함을 보여 주었다. 또한 $\left.{ }^{3} \mathrm{H}\right]$ cytochalasin $\mathrm{B}$ 를 이용한 발현단백질 photolabelling에서는, L-glucose가 존재하 는 상황 하에만 하나의 날카롭게 표지된 peak가, 바이러스 감염된 세포에서 관찰되었다. 감염되지 않은 세포에서 는 이러한 peak는 관찰되지 않았다. 게다가 D-glucose 존재 하에서는 발현된 단백질의 photolabelling이 완전히 억제되어짐을 보여주어, labelling의 입체선택성(stereoselectivity)을 입증하였다. 